\title{
Effect of culture media and temperature on growth and sporulation of Colletotrichum lindemuthianum of urdbean in
} vitro

\author{
M.J. SARDHARA ${ }^{1}$, D.K. DAVARA, A.M. MORADIA AND H.J. KAPADIYA* \\ Main Oilseeds Research Station, Junagadh Agricultural University, JUNAGADH (KARNATAKA) INDIA \\ ${ }^{1}$ Department of Plant Pathology Junagadh Agricultural University, JUNAGADH (KARNATAKA) INDIA
}

\section{ARITCLE INFO}

Received : 05.10 .2015

Revised : 07.02 .2016

Accepted : 21.02 .2016

\section{KEY WORDS :}

Blackgram (Vigna mungo L. Hepper), Culture media, Temperature

*Corresponding author:

Email: hjkapadiya@jau.in

\begin{abstract}
Anthracnose (Colletotrichum lindemuthianum) fungus is an important in the urdbean legumes crop. In the present investigation, the rate of growth of Anthracnose $(C$. lindemuthianum) has been compared in various temperature, culture media solid and liquid while in case solid media types viz., simple PDA (Potato Dextrose Agar), Potato carrot sucrose agar, Carrot juice agar, Blackgram leaf extract agar, Richard's agar, Czapeck's (Dox) agar, Asthana and Hawker's agar had tested. Among all the solid media tested, maximum mycelial growth was obtained in Potato dextrose agar medium $(80.04 \mathrm{~mm})$, which was statistically at par with Richard's agar medium $(76.52 \mathrm{~mm})$.Similarly in the liquid media, maximum dry mycelial weight was recorded in Richard's broth medium (444.34 mg) after 10 days of inoculation which was significantly superior over rest of the broth medias and followed potato dextrose agar broth $(429.03 \mathrm{mg})$. Temperature plays an important role in infection and disease development. Maximum mean colony diameter of fungus was recorded at temperatures of $30^{\circ} \mathrm{C}(80.92 \mathrm{~mm})$ and $25^{\circ} \mathrm{C}(78.62$ $\mathrm{mm})$ which was significantly superior over all other temperatures. Lowest mean colony diameter was obtained at temperatures of $10^{\circ} \mathrm{C}(24.01 \mathrm{~mm})$ and $40{ }^{\circ} \mathrm{C}(21.37 \mathrm{~mm})$. This is important for further study of disease management.
\end{abstract}

How to view point the article : Sardhara, M.J., Davara, D.K., Moradia, A.M. and Kapadiya, H.J. (2016). Effect of culture media and temperature on growth and sporulation of Colletotrichum lindemuthianum of urdbean in vitro. Internat. J. Plant Protec., 9(1) : 47-51. 